\title{
MAXWELL BODENHEIM AND THE THEATRE
}

MAURICE M. ChaRney, a graduate of Harvard University who holds a doctorate from Princeton University, taught at Hunter College before coming to Rutgers in 1956 . He is particularly interested in Shakespeare and contemporary literature.

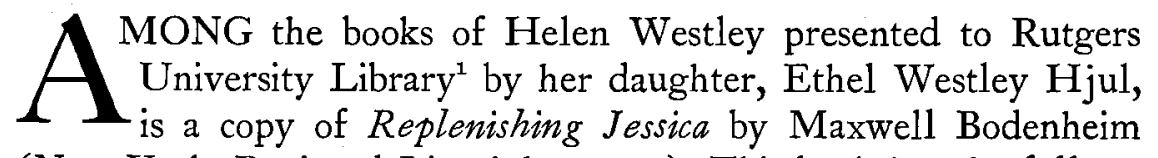
(New York, Boni and Liveright, 1925). This book has the following presentation on the flyleaf (see Illustration): "To Helen Westley, who has defied corruptions in the interest of morbid mazurkas held in spite of the connivance of midnight, and whose intuitive incoherences are often better than the tiny clarities of more articulate beings,

From her friend,

Maxwell Bodenheim."

Helen Westley was one of the organizers of the Washington Square Players, a "little theatre" group which was "born spontaneously" with an impromptu performance of Dunsany's The Glittering Gate in the Washington Square Bookshop. The group gave its first public performance on February I9, I9I5, at the Bandbox Theatre on East 57 Street and Third Avenue. It proposed to do "realistic, romantic, and frivolous plays"s which were ignored by the commercial theatres of the time. It included among its members such actors as Katharine Cornell, Roland Young, and Frank Conroy, and such stage designers as Lee Simonson, Rollo Peters, and Robert Edmond Jones. It was from the Washington Square Players that the Theatre Guild evolved in 1919, with Helen Westley as one of the original Board of Managers. She appeared in one Theatre Guild play each season, chiefly in "character" roles, until she entered films

${ }^{1}$ I am indebted to Mr. Robert G. Williams for calling my attention to this book, and to Mr. Alfred Kreymborg for patiently supplying information about Bodenheim. Mr. Kreymborg is presently at work on a long poem on Bodenheim called "The Praise of the Dead."

${ }^{2}$ Oliver M. Sayler, Our American Theatre, New York, 1923, p. 77.

${ }^{3}$ Thomas H. Dickinson, The Insurgent Theatre, New York, I917, p. I 75. 
in 1934 , but in 1939 she returned to the stage as the grandmother in The Primrose Path at the Biltmore Theatre. She died in 1942 in Middlebush, New Jersey, at the age of 63.

Maxwell Bodenheim and Helen Westley may have been acquainted through the group of artists and intellectuals who gathered in such Greenwich Village rendezvous as Polly's Restaurant or the Washington Square Bookshop (run by Albert and Charles Boni). Maxwell Bodenheim was associated with the Playwrights' Theatre of the Provincetown Players, celebrated for its presentation of O'Neill. After two successful summers at the Wharf Theatre in Provincetown, Massachusetts, this group opened in New York in the winter of I9I 6 at I 39 Macdougal Street. In the next year's season (19I7-I918), two plays of Maxwell Bodenheim were presented: Knot-Holes and The Gentle Furniture Shop. ${ }^{4}$ These were directed by Alfred Kreymborg, and Bodenheim acted in both of them. On the same program were Funiculi-Funicula by Rita Wellman and Ile by Eugene O'Neill. Bodenheim also wrote plays for the Player's Workshop in Chicago: Brown, I9I6 (with William Saphier); Poet's Heart, I9I7; and Mrs. Margaret Calhoun, I9I7 (Ben Hecht and Maxwell Bodenheim). ${ }^{5}$

Replenishing Jessica, which created a furor over its supposed obscenity-about which Jimmy Walker asserted that no girl has ever been seduced by a book ${ }^{6}$ - has many references to plays, playgoing, and theatre people. All the plays Jessica sees seem to ridicule the commercial theatre of the time, as the one about "a minister and a courtesan marooned on a tropical island" (p. 54), or another about "a pair of green stockings owned by a Duchess but found in a servant girl's room in the chateau by the Duke himself, who had gone there for no intrinsically worthy purpose" (p. I 55). To Jessica, as theatre critic, "The trick of all successful realistic plays is to give the characters the vernacular that they would use in actual life, and all of the uppermost foibles in conduct and appearance that people of their kind would have, while at the same time assigning these people theatrical, high-pitched, and preposterous motives and plots" (p. 55). These

4 Sayler, American Theatre, p. 335.

${ }^{5}$ Dickinson, Insurgent Theatre, p. 242.

'S. J. Perelman, "Cloudland Revisited," Neq Yorker, XXV (July 9, 1 949), 16. 
strictures are like those that the "little theatre" groups of the time were making against Broadway.

Perhaps one may think of Jessica's endless seductions as a sort of histrionic exercise, for "When women are living in a time that is neither romantic nor swashbuckling, they expose their bodies more, because the men whom they know are too tired and prosaic to exert their imaginations in the matter, and require at least the beginning of revealment to make them succumb to the woman's charms" (p. 93). Like the actors with whom she becomes involved at the end of the novel, her "most personal and private relations with men and women were never free from a tinge of hysterical posturing at best. It was the penalty which they paid for adapting themselves to the thoughts and emotions which other people ordered them to express behind the footlights, and to the tens of rôles which were often not a part of the actor's deeper nature, for thus they became eager to devise equally volatile and attractive lines and actions, when the grease paint was removed" (pp. 250-5I ). Thus Jessica's barren existence can only be replenished by contact with actual life and by experiencing love for another person.

\section{EditoR's Note}

This is the first issue of the Rutgers Library Journal under the editorship of Dr. Arthur C. Young, the third editor to guide the Journal in its twenty-one year history. Dr. Rudolf Kirk edited the Journal from 1937 to 1948 ; he was followed by Dr. Leslie $A$. Marchand, who was editor from 1948 to 1957. 


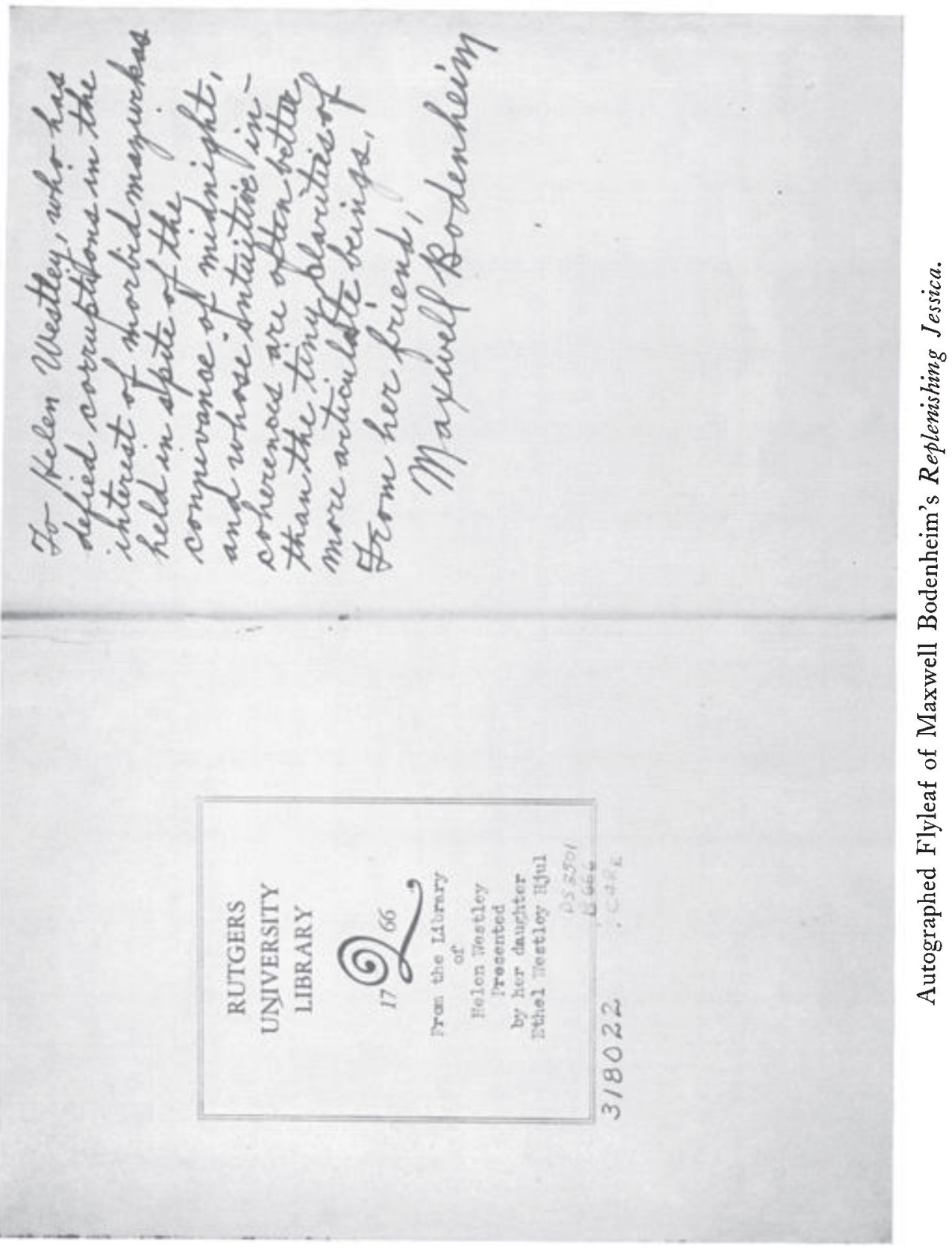

